\title{
STATISTICAL PROOF AND THEORIES OF DISCRIMINATION
}

\author{
DOUGLas LAYCOCK*
}

Barbara Norris's article explains the relationship among disparate treatment theory, disparate impact theory, and multiple regression. ${ }^{1}$ It is a powerful combination. It is altogether too powerful; it proves far too much.

The basic crunch on employers comes from the combination of the disparate treatment and disparate impact theories. Disparate treatment theory requires employers to hire randomly or on some measure of merit. Most choose merit, at least in part. But disparate impact theory is suspicious of all measures of merit; employers must justify each measure used with prohibitively expensive validation studies. The combination is a great onetwo punch for plaintiffs: charge the employer with disparate treatment, and when he explains the rejection of women or minorities with measures of merit, charge him with disparate impact on the basis of each and every defense. This strategy has been available since Griggs v. Duke Power $\mathrm{Co}^{2}{ }^{2}$ have been telling my students about this for years, and Sullivan, Zimmer, and Richards put it in their treatise. ${ }^{3}$ Lots of plaintiffs' lawyers also must have thought of it. Barbara Norris suggests that Segar v. Smith ${ }^{4}$ is the first opinion to set out the whole scheme. That is surprising, if true.

Statistical evidence greatly increases the power of this analytic scheme. With statistics, a plaintiff can raise a strong presumption of disparate treatment without examining the qualifications of a single employee or applicant. But there are unexamined assumptions in this approach. All statistical techniques depend on technical assumptions that are rarely met in the real world. Indeed, a good technique for defense lawyers is to hire mathematical statisticians, generally found in university departments of statistics or mathematics, who will often testify that none of the assumptions are met and plaintiff's statistics prove nothing. Some of these experts seem to think the assumptions are never met and statistics are entirely useless for any purpose; such views are apparently a source of prestige among

Copyright (C) 1986 by Law and Contemporary Problems

* Fulbright \& Jaworski Professor and Associate Dean for Academic Affairs, University of Texas at Austin School of Law. I am grateful to Teresa Sullivan and Jay Westbrook for helpful comments on earlier drafts, and to Professor Sullivan for patient answers to my questions about statistics.

1. Norris, A Structural Approach to Evaluation of Multiple Regression Analysis as Used to Prove Employment Discrimination: The Plaintiff's Answer to Defense Attacks of "Missing Factors" and "Pre-Act Discrimination," LAw \& Contemp. Probs., Autumn 1986, at 65.

2. 401 U.S. 424 (1971).

3. C. Sullivan, M. Zimmer \& R. Richards, Federal Statutory law of Employment Discrimination $\$ 1.4$, at $18,33(1980)$. 66.

4. 738 F.2d 1249 (D.C. Cir. 1984), cert. denied, 105 S. Ct. 2357 (1985); see Norris, supra note 1, at 
mathematicians. The sensible plaintiff's response is to hire applied statisticians, generally found in university departments of social science, "think tanks," or consulting firms, who have thought seriously about which assumptions can be relaxed and by how much without doing serious damage to the resulting inferences. Many statistical techniques are said to be robust against their assumptions, which means that there is relative freedom to relax the assumptions without doing serious damage to the resulting inferences. Robust statistical tests can be put to good use in the real world.

Some assumptions, however, are indispensable. Most statistics in employment discrimination cases compare two populations, such as blacks and whites or men and women. One assumption that can never be relaxed is that the two populations are the same in all respects except for the possible difference under investigation and for any differences that have been controlled. If the two populations are a little bit different, the inference will be a little bit off, but usable. If the two populations are a lot different, the inference will be worthless. The assumption is acknowledged in International Brotherhood of Teamsters $v$. United States, ${ }^{5}$ the case that sets out the theoretical basis for statistical evidence in Title VII cases. The Court explicitly assumes that but for discrimination, the employer's work force would in the long run mirror the racial composition of the labor force from which it was hired. ${ }^{6}$ That conclusion requires the further implicit assumption that the black and white populations are substantially the same in all relevant ways, so that any differences in result are attributable to discrimination. ${ }^{7}$

Some variation of that assumption is critical to all statistical evidence of disparate treatment. It is a powerful and implausible assumption: the two populations are assumed to be substantially the same in their distribution of skills, aptitudes, and job preferences. Two hundred and fifty years of slavery, nearly a century of Jim Crow, and a generation of less virulent discrimination are assumed to have had no effect; the black and white populations are assumed to be substantially the same. All the differential socialization of little girls that feminists justifiably complain about is assumed to have had no effect; the male and female populations are assumed to be substantially the same.

This assumption, which is so critical to statistical disparate treatment cases, is fundamentally inconsistent with the policy premise of disparate impact theory. The explicit premise of disparate impact theory is that women and minorities have suffered from discrimination. Measures of skill and merit are suspect because discrimination has left many minorities with fewer and less developed skills. Griggs v. Duke Power Co., the seminal disparate impact case, relies explicitly on the history of segregated and inferior education for

5. 431 U.S. 324 (1977).

6. Id. at 339 n. 20 .

7. This assumption is not inherent in disparate treatment theory, but it is inherent in statistical proof of disparate treatment. The requirement that the compared groups be substantially the same for statistical proof parallels the requirement that the compared individuals be similarly situated for individual proof. 
blacks in North Carolina schools. ${ }^{8}$ So disparate impact theory insists that employers require only those skills essential to the job. To require skills unnecessarily is to exclude minorities unnecessarily.

It should now be clear what is wrong with the one-two punch of turning all disparate treatment defenses into disparate impact claims: the two theories are inconsistent. The disparate treatment half of the strategy assumes that the black and white populations, or the male and female populations, are identical. The disparate impact half simultaneously assumes that they are greatly different. This pair of inconsistent assumptions lets the plaintiff "prove" discrimination, but the proof is invalid.

The introduction of multiple regression analysis further increases the power of the technique, but it does not eliminate the underlying fallacy. Multiple regression is a far more sophisticated tool than the simple standard deviation analysis in International Brotherhood of Teamsters. It is one of a number of techniques for standardizing disparate populations. Another way to say it is that multiple regression allows you to control for known differences between the two populations. When properly used, multiple regression can measure the impact of all the factors suspected to contribute to differences in employment history, and can show how much of the difference is due to each cause.

The technique also measures the residual difference unexplained by the factors put into the equation. It is common in Title VII litigation to attribute the entire residual difference to discrimination, but that is incorrect. The residual difference represents the sum of all other factors contributing to the difference in employment history. Regression analysis assumes that these factors are minor and substantially independent of each other. ${ }^{9}$ If the investigator suspects that much of the residual difference is caused by an identifiable factor, he should put that factor into the equation as an independent variable. ${ }^{10}$

One way to estimate the effect of discrimination is to include in the equation a dummy variable for race or sex. ${ }^{11}$ For example, whites might be recorded as zero and blacks as one. Then, if all the assumptions are reasonably met, the coefficient of the dummy variable will measure discrimination's contribution to the differences in employment history. This interpretation assumes that there are no significant interaction effects between the dummy variable and the other independent variables; fortunately, it is possible to test whether that assumption is met. After the independent effect of race or sex has been measured by the dummy variable, there will probably still be an unexplained residual difference.

Another way to estimate the effect of discrimination is to compute separate regression equations for blacks and whites or for men and women. Then,

8. 401 U.S. 424, 430 (1971).

9. H. Blalock, Social Statistics $367,445-46$ (2d ed. 1972).

10. Id. at $367-68,450$.

11. For an explanation of dummy variables, see id. at 498-502. For an illustration of their use in the employment discrimination context, see Norris, supra note 1, at 67-68. 
differences in the coefficients of explanatory variables indicate differences in the experience of the races or the sexes. ${ }^{12}$ This technique is seldom used, perhaps because the resulting equations are harder to interpret. But it has two significant advantages: it requires fewer assumptions, and it preserves much more information. If the experience of blacks and whites has been greatly different, including blacks and whites in the same regression equation produces a composite equation that does not accurately reflect the experience of either race. The classic illustration is the man submerged in boiling water below the waist and encased in ice above the waist. One might say that he is comfortable on average, but that would be wrong. Including widely disparate groups in a single regression equation involves the same fallacy.

Like all other statistical techniques, multiple regression depends on certain assumptions. The great advantage of multiple regression is that it is not necessary to assume that the black and white populations are identical. It is enough to assume that they are identical in all relevant ways not controlled for in the regression equation. But this assumption is crucial. ${ }^{13}$

In theory, the investigator can control for any number of known differences by adding more variables to the equation. In practice, there are sharp limits on variables for which he can control. First, adding more variables divides the two populations into smaller and smaller subgroups or cells. The subgroups quickly become too small to support statistical inferences; differences in small subgroups often result from random variation. Therefore, the more variables in the equation, the larger the population must be. ${ }^{14}$ If the population is all the employees of a particular employer, it may be too small to regress on many variables simultaneously.

Second, all variables must be expressed numerically. That obstacle is not insuperable; subjective evaluations of training or job performance can be expressed in numerical scales. But then the third obstacle appears. Title VII law is suspicious of subjective judgments. ${ }^{15}$ Prejudiced employers might use subjective judgments to cover up discrimination, and it is burdensome to review the employer's subjective judgments. So Title VII regression equations are largely limited to variables that do not depend on anyone's

12. For an example of this technique, see Sullivan, The Occupational Prestige of Women Immigrants: A Comparison of Cubans and Mexicans, 18 InT'L Migration Rev. 1045 (1984). This article uses four separate equations to explain differences in occupational prestige in the United States of Cuban men, Cuban women, Mexican men, and Mexican women. The same independent variables are used in each equation, but there are sharp differences in the effects of each variable in each of the four equations. A single regression equation for "Hispanic immigrants" would have concealed these differences and produced a misleading average. A single equation with dummy variables for sex and ethnicity would have shown that there were differences among the four sexual and ethnic groups, but such an equation would have concealed the nature of those differences.

13. H. BLALOCK, supra note 9 , at 367.

14. Statisticians use various rules of thumb for the minimum number of cases necessary to support analysis of an additional variable. For example, one text recommends that there be at least fifty persons in each major cell of the analysis. A. Pollard, F. Yusuf \& G. Pollard, Demographic Techniques 130 (2d ed. 1981).

15. See, e.g., James v. Stockham Valves \& Fittings Co., 559 F.2d 310, 345 (5th Cir. 1977), cert. denied, 434 U.S. 1034 (1978); Norris, supra note I, at 65-66. 
subjective judgment. Examples are years of education and years of experience.

The assumption that the two populations are substantially the same in those respects that depend on subjective judgment is again contrary to reality and contrary to the premises of civil rights policy. A regression equation that equates a year in the typical inner city school with a year in a typical suburban school, or a year at North Carolina Central University with a year at Duke University, ignores all the premises of the school desegregation cases. If our society has discriminated against minorities in education, there should be a remedy. As a society, we still owe the victims of that discrimination an effective education. But it does not follow that an employer is guilty of disparate treatment in employment when he hires or promotes a better educated applicant.

The fourth obstacle to including explanatory variables in the regression equation is disparate impact theory. Whether subjective or objective, all factors used to explain differences in employment success must be validated. That is, it must be shown that the factors really predict better job performance or justify better pay. ${ }^{16}$ Formal validation is difficult and expensive. Again, the one-two punch of combined disparate treatment and disparate impact theory is based on inconsistent premises. Disparate impact theory takes explanatory variables out of the equation because minorities have been deprived of the chance to acquire skills. But when the court removes these variables and then interprets the coefficient of the dummy variable for race or sex as discrimination (or, more egregiously, when it interprets the residual difference as discrimination), it is assuming that blacks and whites have identical distributions of those very same skills.

In theory, all of this is merely a device for shifting the burden of proof. An employer can rebut a disparate impact case by validating his selection criteria, and he can rebut a statistical disparate treatment case by showing that the two populations are not identical. However, these opportunities for rebuttal are more theoretical than real. With respect to disparate impact, the Equal Employment Opportunity Commission (EEOC) and some of the lower courts seem determined to make validation impossible. ${ }^{17}$ The Supreme Court cases

16. See generally Albemarle Paper Co. v. Moody, 422 U.S. 405, 425-39 (1975).

17. The relevant division of the American Psychological Association criticized the Equal Employment Opportunity Commission's (EEOC) 1970 testing guidelines as "professionally unrealistic and effectively unattainable." Brief for the Division of Industrial-Organizational Psychology of the American Psychological Association as Amicus Curiae, at 20, Washington v. Davis, 426 U.S. 229 (1976), reprinted in 88 LANDMARK BRIEFs and ARguments of the Supreme Court of the United States: Constitutional Law 281, 309 (1977). The 1978 Uniform Guidelines on Employee Selection Procedures were delayed by the EEOC's insistence on testing requirements that the other enforcement agencies found unworkable. That disagreement is reviewed from the perspective of the Civil Service Commission in Seelman, Employment Testing Law: The Federal Agencies Go Public with the Problems, 10 URb. LAw. 1 (1978). Eleanor Holmes Norton, Chair of the EEOC during the Carter Administration, stated her fear that employers would find ways to validate tests and the valid tests would still have disparate impact. Transcript of EEOC Commissioners Meeting, December 22, 1977, quoted in Chamallas, Evolving Conceptions of Equality Under Title VII: Disparate Impact Theory and the Demise of the Bottom Line Principle, 31 UCLA L. Rev. 305, 377 n.334 (1983). 
are mixed. ${ }^{18}$ With respect to disparate treatment, rebuttals are largely limited to objective criteria reflected in the employer's records. No one can read all or even most of the cases in this area, but I know of only one case in which the employer has successfully relied on general social and economic data to show that the two populations compared are widely different. ${ }^{19}$

The astonishing thing about the difficulty of rebuttal is that neither side believes the two populations are identical. Plaintiffs even more than defendants believe that women and minorities have suffered from discrimination. A set of rules that imposes a nearly insuperable burden of proving a fact that both sides believe to be true cannot be explained or justified on the ground that it merely shifts the burden of proof.

All of this also helps explain the recurring complaints that it is difficult for plaintiffs to win one-on-one discrimination cases. The conventional wisdom is that motive is hard to prove, and that courts are reluctant to impute bad motives on the part of employers. There is something to both of those points, and courts should infer bad motive from suspicious circumstances more often than they do. ${ }^{20}$ The standard is preponderance of the evidence, not beyond a reasonable doubt.

But something else is going on in the one-on-one cases. The false assumption that skills and preferences are identically distributed among all racial and sexual groups is largely irrelevant to the one-on-one cases. Judges can and do examine the qualifications of an actual plaintiff. Sometimes it will appear that the plaintiff was the victim of discrimination. Sometimes it will appear that he was less qualified than the competing applicant. That unfortunate possibility is assumed away in the statistical cases.

Segar $v . S m i t h^{21}$ is a good example of a case in which the court failed to understand all the reasons why statistical and individual proof might point in opposite directions. The district court found statistical proof of discrimination even though it did not find for plaintiffs on a single alleged discriminatory incident. ${ }^{22}$ The court of appeals was untroubled; it saw no reason to require "anecdotal" evidence to supplement the statistics:

18. Compare Washington v. Davis, 426 U.S. 229, 248-52 (1976) (Court let employer use one paper and pencil test to validate another paper and pencil test) with Albermarle Paper Co.v. Moody, 422 U.S. 405, 425-36 (1975) (Court adopted stringent EEOC guidelines on test validation); compare Dothard v. Rawlinson, 433 U.S. 321 , 331-32 (1977) (Court refused to assume relationship between size and strength) with New York City Transit Auth. v. Beazer, 440 U.S. 568, 587 (1979) (Court disposed of business necessity issue in one sentence plus a footnote, finding it sufficient that excluding methadone patients from all positions reduced the burden of monitoring employees).

19. EEOC v. Sears, Roebuck \& Co., No. 79-C-4373 (N.D. Ill. Feb. 3, 1986) discussed in N.Y. Times, Feb. 4, 1986, at 8 , col. 1 .

20. Perhaps the classic example of refusal to infer motive occurred in Griggs v. Duke Power Co., 401 U.S. 424 (1971). The employer adopted stringent new testing requirements on the day Title VII took effect, but the Court refused to infer a racial motive. Another egregious example is Garcia v. Gloor, 618 F.2d 264 (5th Cir. 1980), cert. denied, 449 U.S. 1113 (1981), in which plaintiff was discharged for speaking one sentence in Spanish. The court found no evidence that the discharge or the rule against Spanish was motivated by ethnic hostility. Id. at 270.

21. 738 F.2d 1249 (D.C. Cir. 1984), cert. denied, 105 S. Ct. 2357 (1985).

22. Id. at 1277 . 
Such a rule would reflect little more than a superstitious hostility to statistical proof, a preference for the intuitionistic and individualistic over the scientific and systemic. It is not difficult to understand that discrimination might exist even when affected individuals can point to no specific instances of an employer's discriminatory conduct. The days of Bull Connor are largely past; discrimination now works more subtly. ${ }^{23}$

The problem is more difficult than that. An employer can easily discriminate without making statements that reveal his motive. It is possible, but much more difficult, to discriminate without leaving a record of deserving women or minorities who were passed over in favor of white males. If some of the white males were less deserving, or if a disproportionate number of the ties go to white males, there is "anecdotal" evidence of discrimination. If no such incidents can be found and the employer has not destroyed his records, the court has to consider the possibility that there is something wrong with the statistics. It is quite likely that the statistics are invalid because the populations are not comparable, and that the imbalance in defendant's workforce is more the result of differences in the two populations than the result of discrimination. That may not invariably be true; some discriminators are exceptionally clever. But differences between the two populations are far more likely than discrimination that leaves no trace. The court's contrary assumption leaves it vulnerable to its own epithets: its blind faith in statistical evidence without consideration of the assumptions underlying the statistical techniques reflects a superstitious faith in the pseudoscientific. It is not scientific to do statistical comparisons of widely different populations without controlling for the differences.

Of course, plaintiffs do not win all statistical cases, either. The combination of disparate impact and statistical proof of disparate treatment is a juggernaut, but plaintiffs can mess up the statistics badly enough to lose the advantage. ${ }^{24}$ More important, defendants and some judges have tried to throw sand in the gears. Stuck with premises that led to results they could not live with, some judges have refused to go along, reallocating the burden of proof, ${ }^{25}$ restricting the scope of disparate impact theory, ${ }^{26}$ or throwing up hyper-technical objections that plaintiffs properly view as illegitimate. ${ }^{27}$

23. Id. at 1278 .

24. E.g., EEOC v. International Business Machs. Corp., 583 F. Supp. 875, 898-99 (D. Md. 1984) (plaintiff introduced a multiple regression equation that neglected to control for seniority, job level, or education).

25. See Coates v. Johnson \& Johnson, 756 F.2d 524, 542-45 (7th Cir. 1985) (plaintiffs bear the burden of proving that defendants' explanatory variables are tainted by discrimination).

26. Payne v. Travenol Laboratories, 673 F.2d 798, 816-17 (5th Cir.), cert. denied, 459 U.S. 1038 (1982); Pouncey v. Prudential Ins. Co., 668 F.2d 795 (5th Cir. 1982); Rivera v. City of Wichita Falls, 665 F.2d 531, 539-40 (5th Cir. 1982).

27. Perhaps the best known example is New York City Transit Auth. v. Beazer, 440 U.S. 568 (1979), in which the Court found no evidence that discharging or refusing to hire drug abusers on methadone maintenance had disparate impact on blacks or Hispanics. The evidence showed that $63 \%$ of the patients in New York City's public methadone maintenance programs were black or Hispanic. The Court found this statistic irrelevant to the plaintiff class, which consisted of methadone patients who had been successfully maintained on methadone for one year. The Court speculated that private methadone patients might be disproportionately Anglo, and that Anglo methadone patients might succeed more frequently than minority methadone patients. Neither objection had been raised in the trial court, so there was no evidence either way. But the disparate 
The solution is to address the underlying fallacy. For some highly skilled jobs, I do not think plaintiffs make even a prima facie case by relying on statistics about objective minimum credentials. By highly skilled jobs, I do not mean only professional jobs or the traditional skilled crafts. In an economy with increasingly complex machinery and instruction manuals, both of which are frequently changed or replaced, strong reading skills are important in a wide range of jobs traditionally considered semiskilled. Unfortunately, there is no reason to assume that reading skills are now distributed without regard to race. Some individuals are wholly unemployable at any job. ${ }^{28}$ Those misfortunes affect all races and both sexes, but probably not in proportionate numbers.

Whatever the standard for shifting the burden of proof to the employer, the essential reform is that rebuttal must be feasible. In disparate impact cases, proof of validity must be possible in the real world at reasonable expense. There are ways to make this possible. Some defenders of the existing legal rules have argued that validation is much easier than a reading of the case law would suggest, in part because content validation is inexpensive and applicable to a broad range of tests. ${ }^{29}$ Other researchers have argued that data from criterion validation studies can be cumulated and generalized. ${ }^{30}$ This approach avoids the expense required for every employer to replicate the studies. More important, it greatly increases the statistical power to distinguish valid from invalid tests. ${ }^{31}$ Single-employer studies typically involve small samples of employees with similar scores: good enough to get hired but not so good that they found a better job. Because studies on such small and homogenous groups tend to be inconclusive, employers lose simply because they bear the burden of proof.

In disparate treatment cases, proof of differences between the two populations must be admissible. Once admitted, such evidence must not be subjected to a level of scrutiny that makes it futile. Subjective evaluations must be given reasonable weight and, if necessary, reviewed on an individual basis. For large employers, the court might review a random sample of subjective evaluations to see if they were being used to hide discrimination.

impact would not have been eliminated even if the private patients had been exclusively Anglo. The disparate impact could have been eliminated if Anglo methadone patients succeeded two or three times as often as minority methadone patients, but there was no basis to assume such a large difference in success rates. It is possible that Anglo heroin addicts retain some social advantage that helps them succeed on methadone maintenance, but it is equally plausible to assume that heroin addicts do not differ much by race. It is surely implausible to assume that Anglo methadone patients succeed two or three times as often. I would have accepted plaintiffs' proof and required the employer to rebut it before reaching the implausible conclusion that discrimination against a class of methadone patients in New York City has no disparate impact on blacks and Hispanics.

28. For example, in New York City Transit Auth. v. Beazer, 440 U.S. 568 (1979), the Supreme Court concluded that one-third of methadone patients were "unquestionably . . . unemployable." Id. at 577. This characterization was based on the trial court's findings of fact. Id. at 577 n.14.

29. Doverspike, Barret \& Alexander, The Feasibility of Traditional Validation Procedures for Demonstrating Job-Relatedness, 9 LAW \& Psychology Rev. 35 (1985).

30. Schmidt \& Hunter, Employment Testing: Old Theories and New Research Findings, 36 АM. Psychologist 1128 (1981).

31. Id. at 1128,1132 . 
Reviewing subjective evaluations is burdensome, but the alternatives are to exclude them or defer to them blindly. Excluding them will never work, because there are subjective differences among employees. Deferring to them blindly will never work, because employers do use them to discriminate. Both of those alternatives lead to results wholly out of touch with reality.

The same lessons are applicable to quota remedies, if they survive Firefighters Local Union No. 1784 v. Stotts, ${ }^{32}$ and to affirmative action plans. If a court or employer sets a goal without considering subjective differences in skill distributions, the goal will be wholly unrealistic. Such a goal will be impossible to meet except by hiring minorities who are much less qualified than many of the rejected nonminorities.

I do not suggest that public policy can ignore the effects of past discrimination. I think we are morally bound to address those effects. We need more research to determine how to equalize educational opportunity, more investment in education to implement what we learn, and more remedial education for victims of past discrimination. We need more effective public health and nutrition programs, and more effective social services for troubled families and especially for preschoolers. We need to find ways of encouraging family stability and a vastly lower rate of illegitimacy and teenage parenthood. These are not "blame-the-victim" solutions, as Marilyn Yarbrough's article suggests. ${ }^{33}$ They are solutions directed to the problem. If the problem is that many of our citizens are deprived of a chance to acquire skills, the solution is to develop their skills, not to hire and promote them as though they already had such skills.

A remedy that improved the skills of disadvantaged citizens would be a societal investment in human capital that would surely pay for itself. But the political system resists the expense of the investment, and current employment discrimination law tries to solve the problem without any visible expense. The result is to put the whole burden on employers and marginal white workers. Current discrimination law pressures employers to hire and promote less skilled minorities, but it does little to give minorities the skills of which they have been deprived. The pressures to hire and to promote create demand for minority employees in the most highly skilled jobs that far exceeds the supply of minority workers ready to fill those jobs. Employers susceptible to such pressure are rapidly promoting far too many talented minorities well beyond their Peter Principle level. ${ }^{34}$

Over-promotion is not a solution, but a disaster. It imposes terrible costs on the minorities who receive these promotions and on the competing

32. 467 U.S. 561 (1984).

33. Yarbrough, Disparate Impact, Disparate Treatment, and the Displaced Homemaker, LAW \& CoNTEMP. Probs., Autumn 1986, at 109.

34. The Peter Principle posits that employees who do a good job are promoted. They keep getting promotions until they no longer do a good job. Then, because no one is ever demoted, they stay until retirement in the job they do not do well. L. Peter \& R. Hull, The Peter Principle 24-25 (1969). The Principle is an exaggerated statement of a real risk. For minorities, the risk is aggravated by the pressure to promote them in proportion to their numbers without first correcting the consequences of past discrimination and disadvantage. 
applicants and employees who do not receive them. For the first time in the history of race relations, we are giving the majority a legitimate grievance against minorities. And we are legitimating open racial and ethnic competition over shares of the quota pie. ${ }^{35}$ The consequences of these developments should be horrifying to all who care about nondiscrimination.

\section{POSTSCRIPT}

While this article was in page proof, the Supreme Court decided several relevant cases. First, the Court upheld some remedial uses of racial quotas in voluntary affirmative action plans, ${ }^{36}$ in consent decrees, ${ }^{37}$ and in litigated decrees if the discrimination has been especially egregious or intransigent. ${ }^{38}$ Quotas thus survived the contrary dictum in Firefighters $v$. Stotts. ${ }^{39}$ But there is a new emphasis on tailoring the quota to the impact of the employer's past discrimination on his work force. ${ }^{40}$ Quotas are not supposed to undo the effects of societal discrimination. ${ }^{41}$ It will be all the more important to base goals and quotas on an accurate assessment of the distribution of skills in the population.

Second, in Bazemore v. Friday, the Court had its first encounter with multiple regression: the Court unanimously held that regression equations may help prove discrimination by a preponderance of the evidence even though some possibly relevant variables are omitted. ${ }^{42}$ As the unanimous decision suggests, the Court's holding was uncontroversial on the facts of the case. One of the regression equations in the record used the employer's subjective evaluation of performance as a variable. ${ }^{43}$ There was evidence that the other missing variables were unimportant or that they would not tend to reduce or explain the racial differences in pay. ${ }^{44}$ And the statistical evidence was supported by extensive anecdotal evidence. ${ }^{45}$ The proof of discrimination in Bazemore did not depend on the fallacies discussed in this article, and the Court had no occasion to address them.

35. For a detailed example, see Van Alstyne, Rites of Passage: Race, The Supreme Court, and the Constitution, 46 U. CHI. L. REv. 775, 804-08 (1979).

36. Wygant v. Jackson Bd. of Educ., 106 S. Ct. 1842, 1850-52 (1986) (plurality opinion), reh'g denied, 106 S. Ct. 3320 (1986); id. at 1853-54 (O'Connor, J., concurring).

37. Local No. 93, Int'l Ass'n of Firefighters v. City of Cleveland, 106 S. Ct. 3063 (1986).

38. Local 28, Sheet Metal Workers' Int'l Ass'n v. EEOC, 106 S. Ct. 3019 (1986) (plurality opinion).

39. Firefighters Local Union No. 1784 v. Stotts, 467 U.S. 561, 579-83 (1984), discussed in text supra note 32.

40. Local 28, Sheet Metal Workers' Int'l Ass'n v. EEOC, 106 S. Ct. 3019, 3050-52 (1986); Wygant v. Jackson Bd. of Educ., 106 S. Ct. 1842, 1848-50 (1986) (plurality opinion); reh 'g denied, 106 S. Ct. 3320 (1986); id. at 1857 (O'Connor, J., concurring).

41. Wygant v. Jackson Bd. of Educ., $106 \mathrm{~S}$. Ct. 1842, 1847-48 (1986) (plurality opinion); reh'g denied, 106 S. Ct. 3320 (1986); id. at 1854 (O'Connor, J., concurring).

42. Bazemore v. Friday, $106 \mathrm{~S}$. Ct. $3000,3007-11$ (1986).

43. Id. at 3009,3011 n.15.

44. Id. at $3010-11$.

45. Id. at 3009-10. 